Журнал«Герспективитаіновації науки

(Серія «Гедагогіка», Серія«ГЕихологія», Серія«Медицина»

№1(6) 2022

УДК 373.5.016:51

https://doi.org/10.52058/2786-4952-2022-1(6)-250-259

Куземко Леся Валентинівна кандидат педагогічних наук, доцент кафедри педагогіки та психології Київського університету імені Бориса Грінченка, бул. І. Шамо, 18/2, м. Київ, 02154, тел.: (044) 295-35-24, https://orcid.org/0000-0003-3070-6322

Чуба Дарина Андріївна магістрантка спеціальності 013 «Початкова освіта» Київського університету імені Бориса Грінченка, бул. І. Шамо, 18/2, м. Київ, 02154

\title{
ЗАСТОСУВАННЯ ВЕБКВЕСТІВ У ФОРМУВАННІ НАСКРІЗНИХ УМІНЬ УЧНІВ В УМОВАХ ВПРОВАДЖЕННЯ РЕФОРМИ НУШ
}

Анотація. У статті висвітлено результати студіювання Державних стандартів початкової i базової середньої освіти щодо наступності у формуванні наскрізних умінь здобувачів освіти. 3'ясовано характеристику наскрізних умінь та виокремлено показники їхньої сформованості в учнів суміжних циклів навчання: другого - початкової освіти й адаптаційного базової середньої освіти. Виявлено певну зорієнтованість конкретних освітніх галузей на забезпечення розвитку наскрізних умінь учнів обох циклів.

Наведено результати емпіричного дослідження сформованості наскрізних умінь учнів 3-4 та 5-6 класів у порівнянні. 3'ясовано, що організація освітнього процесу в 3-4 класах, яка здійснюється із застосуванням діяльнісного підходу на інтегровано-предметній основі у відповідності 3 реформою НУШ, $\epsilon$ результативнішою у формуванні всіх окреслених стандартом наскрізних умінь у порівнянні з 5-6 класами.

За результатами констатувального етапу дослідження здійснено пошук дієвих форм, методів і засобів формування наскрізних умінь учнів 5-6 класів 3 орієнтацією на кращі практики початкової школи. Одним із ефективних засобів навчання учнів в сучасних закладах загальної середньої освіти визначено вебквести. Вони позитивно оцінені вчителями початкових класів як ефективний засіб активізації самостійної пізнавальної діяльності учнів та формуванні наскрізних умінь.

Представлено зміст розробленого авторського інформаційного ресурсу вебсайту «Розвиток умінь - шлях до успіху!», в якому кожна сторінка присвячена окремому вебквесту. Запропоновані вебквести розроблені 3 урахуванням змісту освітніх галузей і використовувалися з учнями 3-4 та 5-6 класів для формування наскрізних умінь як у процесі навчальної, так i позанавчальної роботи. Отримані у результаті емпіричного дослідження дані, довели ефективність розробленого змістово-технологічного забезпечення 
формування наскрізних умінь учнів 3-4 та 5-6 класів засобами вебквестів.

Ключові слова: вебквести, здобувачі початкової та базової середньої освіти, наскрізні уміння, реформа НУШ, суміжні цикли навчання.

Kuzemko Lesya Valentinovna $\mathrm{PhD}$ in Pedagogics, Associate Professor of the Department of Pedagogy and Psychology Borys Grinchenko Kyiv University, тел.: (044) 295-35-24, https://orcid.org/0000-0003-3070-6322

Chuba Daryna Andriivna Master's degree student Programme subject area 013 «Primary Education» Borys Grinchenko Kyiv University, blvd. I. Shamo, 18/2, Kyiv, 02154

\title{
WEBQUEST USING IN FORMATION CROSS-CUTTING SKILLS OF STUDENTS IN THE CONDITIONS OF IMPLEMENTATION OF NEW UKRAINIAN SCHOOL REFORM
}

\begin{abstract}
In this article revealed results of studying State standards of primary and basic secondary education on continuity in the formation of cross-cutting skills of students. Found out characteristics of cross-cutting skills and singled out indicators of their formation in students of related cycles of studying: second primary education and adaptive - basic secondary education. Revealed certain orientation of specific educational branches to ensure the development of crosscutting skills of students of both cycles.

Presented results of an empirical study of cross-cutting skills formation of students in grades 3-4 and 5-6 in comparison. Found out, that the organization of the educational process in 3-4 grades, which is carried out using activity approach on an integration-subject basis in accordance with the New ukrainian school reform, is more effective in the formation of all cross-cutting skills declared in the Standard in comparison with 5-6 grades.

According to results of the ascertaining stage of the research carried out search for effective forms, methods and means of formation cross-cutting skills of students 5-6 grades with focus on the best practics of primary school. One of the effective means of teaching students in modern institutions of general secondary education defined webquests. They are positively assessed by primary school teachers as an effective means of activating by students self-cognitive activity and formation crosscutting skills.

Presented content of developed author's information resource - website «Skill development is the way to success!», in which each page is dedicated to a separate webquest. Proposed webquests designed

Proposed webquests designed with corresponding of the content of the educational areas of the Standard and were used in working with students 3-4 and 56 grades for formation cross-cutting skills, in the process of educational and extracurricular work. Obtained as a result of empirical research data, proved the
\end{abstract}


effectiveness of the developed content-technological software of formation cross-cutting skills of students 3-4 and 5-6 grades by means of webquests.

Keywords: webquests, students of primary and basic secondary education, cross-cutting skills, New ukrainian school reform, related cycles of studying.

Постановка проблеми. Актуальність пошуку ефективних шляхів формування наскрізних умінь учнів базової середньої освіти зумовлена системним впровадженням Концепції «Нова українська школа» та затвердженням Державного стандарту базової середньої освіти (2020). У відповідності до змісту зазначених документів у 2021 році навчатимуться учні 5 класів пілотних шкіл, а 3 вересня 2022 року всі нинішні четвертокласники. Тому вважаємо надзвичайно актуальним здійснення пошуку таких форм, методів і засобів, які б зацікавили учнів та активізувати їхній потенціал у формуванні наскрізних умінь.

Вивчення практики початкової школи щодо формування наскрізних умінь учнів, аналіз наукових праць щодо застосування сучасних освітніх технологій в закладах загальної середньої освіти (33СО), зосередив нашу увагу на потенціалі вебквестів, як дієвого засобу формування наскрізних умінь здобувачів початкової та базової середньої освіти.

Аналіз останніх досліджень і публікацій. Зміст нормативних документів які супроводжують освітню реформу в З3СО - Концепція НУШ, Державні стандарти початкової і базової середньої освіти, наголошують на необхідності забезпечувати результати навчання здобувачів освіти на основі сучасних знань, здатності їх застосовувати, а також наскрізних умінь - так званих «м'яких» навичок [1; 2]. Останні, часто визначаються науковцями як «навички XXI століття», або «гнучкі навички» (англ. soft skills).

Спільною ознакою для різних тлумачень зазначених умінь $\epsilon$ те, що вони формуються у процесі навчання і саморозвитку, а їхня функція полягає в інтеграції освітніх галузей i забезпеченні взаємозв'язку ключових компетентностей учнів. Так, дослідниця Л. Роміцина зазначає, що наскрізні вміння які формуються на уроках математики співпадають з уміннями, які формуються на інших уроках i сприяють розвитку різних ключових компетентностей учня, а не лише математичної [5, С. 66]. Науковиця I. Колеснікова доводить, що у процесі формування інформаційнокомунікаційної компетентності учнів відбувається розвиток низки наскрізних умінь (вміння досліджувати інформаційний навколишній світ, критично оцінювати інформацію з різних джерел, дотримання етичних, міжкультурних та правових норм інформаційної взаємодії тощо) [3, С. 44].

Аналіз результатів комплексного дослідження рівнів розвитку наскрізних умінь учнів третіх класів початкової школи за результатами впровадження реформи НУШ, проведеного з ініціативи Міністерства освіти і науки України у 2019-2020 pр., дозволило виокремити ті наскрізні уміння, на формування яких необхідно зосередити особливу увагу педагогів. Зокрема це уміння, які 
потребують когнітивних зусиль: здатність висловлювати свої думки, критичне та системне мислення, уміння вирішувати проблеми, інноваційність [4, С. 8-9].

У результаті пошуку ефективних форм, методів і засобів формування виокремлених наскрізних умінь, зосереджено увагу на дослідженнях науковців у галузі інформаційних технологій в освіті (М. Кадемія, Н. Ніколаєва, Н. Кононець, Р. Гуревич та ін.) щодо використання 3 учнями вебквестів. 3'ясовано, що вебквест $є$ певним проєктом i може виступати формою організації та засобом навчання учнів як на уроках, так i в самостійній діяльності. Вебквести часто використовуються вчителями початкових класів у формуванні компетентностей учнів i, на наше переконання, можуть бути дієвим засобом у формуванні наскрізних умінь у здобувачів як початкової так і базової середньої освіти.

Мета статті - висвітлення результатів теоретичного i емпіричного дослідження ефективності вебквестів у формуванні наскрізних умінь здобувачів початкової та базової середньої освіти.

Виклад основного матеріалу. Дослідження ефективності вебквестів у формуванні наскрізних умінь учнів 33СО здійснювалося впродовж 2020-2021 років. Дослідження передбачало чотири взаємопов'язаних етапи: підготовчий; констатувальний, формувальний та контрольний.

На підготовчому етапі (жовтень 2020 р. - лютий 2021 р.) здійснено аналіз змісту Державних стандартів початкової та базової середньої освіти 3 метою визначення характеристики наскрізних умінь учнів суміжних циклів навчання (3-4 і 5-6 класів), наступності у їхньому формуванні та методичних рекомендацій МОН щодо їхнього оцінювання.

Роблено методику дослідження рівнів сформованості наскрізних умінь учнів з урахуванням показників їхньої сформованості за змістом стандартів та рівневою характеристикою їх прояву (узгоджено зі шкалою «Свідоцтво досягнень учнів 3-4 класів та рамкою оцінювання навчальних досягнень учнів базової середньої освіти): початковий («П», 1-3 бали) - потребує значної уваги та допомоги; середній («С» 4-6 балів) - досягає результату за допомогою дорослих; достатній ( «Д» 7-9 балів) - демонструє помітний прогрес; високий («В» 10-12 балів) - має значні успіхи.

Другий етап дослідження (січень-лютий, 2021 р.) - констатувальний, полягав у вивчені рівнів сформованості наскрізних умінь учнів. Дослідження рівнів прояву наскрізних умінь здійснювалося шляхом визначення середніх показників бальних оцінок, отриманих у результаті застосування комплексу методів:

- опитування учнів, 3 метою самооцінювання наскрізних умінь. 3 цією метою розроблено опитувальний аркуш;

- спостереження за навчальною діяльністю учнів i виконанням ними компетентнісних завдань. 3 цією метою підготовлено протокол спостереження iз переліком учнів у класі, характеристикою наскрізних умінь та рівнів їх прояву (на основі свідоцтва досягнень). Впродовж тижня велося 
Журнал«Герспективитаіновації науки

(Серія«Гедагогіка», Серія«ГЕихологія», Серія«Медицина»

№1(6) 2022

спостереження за класом учнів експериментальних груп і фіксувалися результати;

- оцінювання наскрізних умінь учнів вчителями за результатами семестрового контролю. На цьому етапі у дослідженні взяли участь 46 учнів (24 учні 3 класу і 22 учні 5 класу). Проведене дослідження підтвердило припущення, що у початковій школі яка працює за реформою НУШ, достатньо уваги приділяють формуванню наскрізних умінь учнів (табл. 1).

Таблиця 1

Узагальнені дані сформованості наскрізних умінь учнів 3-4 класів у порівнянні (на констатувальному та контрольному етапах дослідження)

\begin{tabular}{|c|c|c|c|c|c|c|c|c|}
\hline \multirow[b]{2}{*}{ Наскрізні уміння } & \multicolumn{4}{|c|}{$\begin{array}{c}3 \text { клас (24 особи) } \\
\text { констатувальний етап }\end{array}$} & \multicolumn{4}{|c|}{$\begin{array}{c}4 \text { клас (24 особи) } \\
\text { контрольний етап }\end{array}$} \\
\hline & $\Pi$ & $\mathrm{C}$ & Д & $\mathrm{B}$ & $\Pi$ & $\mathrm{C}$ & Д & $\mathrm{B}$ \\
\hline читання з розумінням & 4 & 6 & 8 & 6 & 1 & 4 & 7 & 12 \\
\hline $\begin{array}{l}\text { уміння висловлювати власну } \\
\text { думку усно та письмово }\end{array}$ & 4 & 6 & 6 & 8 & 2 & 4 & 4 & 14 \\
\hline критичне та системне мислення & 6 & 7 & 7 & 4 & 4 & 2 & 7 & 11 \\
\hline уміння діяти творчо & 2 & 8 & 10 & 4 & 0 & 3 & 5 & 16 \\
\hline інноваційність & 5 & 6 & 8 & 5 & 3 & 2 & 6 & 13 \\
\hline $\begin{array}{l}\text { уміння логічно обгрунтовувати } \\
\text { позицію }\end{array}$ & 4 & 7 & 7 & 6 & 2 & 3 & 4 & 15 \\
\hline уміння керувати емоціями & 3 & 9 & 6 & 6 & 1 & 2 & 7 & 14 \\
\hline $\begin{array}{l}\text { уміння оцінювати ризики та } \\
\text { приймати рішення }\end{array}$ & 5 & 6 & 8 & 5 & 3 & 3 & 7 & 11 \\
\hline уміння розв'язувати проблеми & 5 & 7 & 7 & 5 & 2 & 4 & 4 & 14 \\
\hline уміння співпрацювати з іншими & 1 & 5 & 9 & 9 & 0 & 3 & 4 & 17 \\
\hline середнє значення & 3,9 & 6,7 & 7,6 & 5,8 & 1,8 & 3 & 5,5 & 13,7 \\
\hline
\end{tabular}

Порівняння отриманих результатів сформованості наскрізних умінь учнів 3 та 5 класі довели, що у процесі навчання у початковій школі, яке здійснюється за реформою НУШ, учні мають дещо вищі результати їхньої сформованості (у відповідності до вікових можливостей визначених Державними стандартами початкової та базової середньої освіти). Зокрема, уміння читання з розумінням в учнів п'ятого класу сформовано на вищому рівні у порівнянні з учнями третього класу, а критичне i системне мислення знаходиться майже на однаковому рівні.

У процесі спостереженням за учнями 5 класу виявлено порівняно невисокий рівень умінь вільно висловлювати свою думку, узгоджувати свої дії у груповій діяльності; низький рівень уміння контролювати свої емоції та наводити аргументи у процесі дискусій; учням складно здійснювати самостійний пошук інформації для розв'язування задачі, планувати діяльність для досягнення результату. Проведений аналіз засвідчив необхідність розроблення ефективного змістово-технологічного забезпечення формування наскрізних умінь засобом вебквестів, яке б сприяло активізації самостійної 
пізнавальної діяльності учнів та у цікавій доступній формі сприяло їхньому розвитку.

Tpemiŭ етап - формувальний (березень - жовтень, 2021 р.), передбачав розроблення та впровадження в освітній процес 33СО вебквестів, спрямованих на формування наскрізних умінь учнів 3-4 та 5-6 класів. 3 метою розроблення змістово-технологічного забезпечення формування наскрізних умінь учнів засобом вебквестів, нами вивчено зміст освітніх галузей та навчальних програм для учнів суміжних циклів: другого - початкової освіти й адаптаційного - базової середньої освіти. Розроблено вебквести, які можуть виконуватися учнями 3-4 і 5-6 класів, з урахуванням рівня сформованості наскрізних умінь за результатами констатувального етапу дослідження. Пропоновані вебквести використовувалися на уроках, у позаурочній діяльності та самостійній роботі. До виконання завдань долучалися учні в міні-групах та індивідуально.

Для зручності використання нами розроблено інформаційний ресурс вебсайт «Розвиток умінь - шлях до успіху!» в якому кожна сторінка присвячена окремому вебквесту: «Гостинність», «Знавець столиці», «Знавець дорожніх знаків», «Хобі», «Новий рік», наведемо короткий опис кількох сторінок.

Сторінка вебквесту «Гостинність», як і всі інші сторінки сайту, містить вступну частину зі зверненням до учня, інструкцію щодо виконання завдань та покликання на інформаційні джерела та онлайн сервіси. Завдання цього квесту - це покроковий план, який допоможе запросити та прийняти гостей. Перше завдання стосується розрахунку часу проведення гостин, 3 урахуванням віддаленості проживання кожного гостя. Учню необхідно прорахувати час, о котрій годині необхідно гостю вийди з дому, затратити на дорогу, щоб вчасно прибути на місце. Тут учні аналізують, порівнюють та обирають час, який буде зручний для кожного, адже за умовами завдання гості живуть в різних містах. Необхідно знайти інформацію про відстань до кожного міста, зручний маршрут, транспорт, розрахувати час та створити спільну (за умови групової роботи) онлайн таблицю. Під час виконання цього завдання формуються такі наскрізні вміння: співпрацювати з іншими, розв'язувати проблеми, оцінювати ризики та приймати рішення, критичне та системне мислення.

Наступними завданнями зазначеного вебквесту є розроблення запрошень для гостей, які учні створюють у запропонованих сервісах (Canva, Jamboard та ін.). Також необхідно обговорити і визначити тематику, дрес-код, меню вечірки. У процесі виконання цього завдання учні знайомляться з етикетом, правилами прийому гостей тощо. Такі завдання формують творчість, інноваційність, здатність висловлювати та обгрунтовувати пропозицію.

Сторінка вебквесту «Знавець столиці» передбачає низку завдань - пошук інформації, перегляд відео, подорожі віртуальними музеями, вирішення проблемних завдань та створення інформаційних буклетів. Для прикладу наведемо одне завдання вебквесту (рис. 1). 


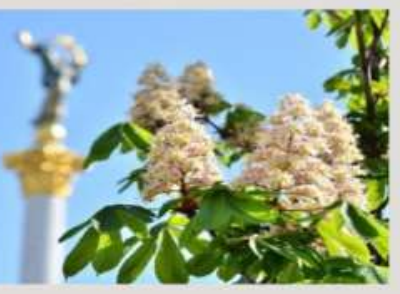

Завдання 8

Tвinf друг розповів, по в жовтні гуляв у парку Києва і

спостерігав за дивним явишем - серед пожовклого листя

різних дерев, він побачпв швіт символа Киева - каштану.

Чи повіриш ти у розповідь товарпша?

Чи може таке трапитися у жовтні?

Якшо може - то за яках умов?

Знайди необхідну інформацію в мережі і спростуй, або

підтверди слова товариша.

\section{Pис. 1. Завдання авторського вебквесту «Знавецьь столиціі»}

У результаті описаного вебквесту в учнів формуються уміння: читання 3 розумінням, критичне мислення, творчість, здатність розв'язувати проблеми, висловлювати власну думку тощо.

Варто зазначити, зо запропоновані учням 3-4 та 5-6 класів вебквести виконувалися як під час уроків, так і в позаурочний час. Вони викликали неабияке зацікавлення і мотивували до самостійності в отриманні нових знань та умінь.

Четвертий етап - контрольний (грудень, 2021 р.) передбачав перевірку ефективності розробленого змістово-технологічного забезпечення формування наскрізних умінь учнів засобом вебквестів. 3 цією метою проведено повторне вивчення рівнів сформованості наскрізних умінь в учнів 4 класу (які на констатувальному етапі дослідження навчалися у третьому класі) та 6 класу (які на констатувальному етапі дослідження навчалися у 5 класі). Дослідження здійснювалася за аналогісю констатувального етапу, результати представлені у табл $2,3$.

Таблиия 2

Узагальнені дані сформованості наскрізних умінь учнів 3-4 класів у порівнянні (на констатувальному та контрольному етапах дослідження)

\begin{tabular}{|c|c|c|c|c|c|c|c|c|c|c|c|}
\hline \multirow[b]{2}{*}{ Наскрізні уміння } & \multicolumn{4}{|c|}{$\begin{array}{c}3 \text { клас (24 особи) } \\
\text { констатувальний етап }\end{array}$} & \multicolumn{7}{|c|}{$\begin{array}{c}4 \text { клас (24 особи) } \\
\text { контрольний етап }\end{array}$} \\
\hline & $\Pi$ & $\mathrm{C}$ & Д & $\mathrm{B}$ & & $\Pi$ & & $\bar{C}$ & & & B \\
\hline читання з розумінням & 4 & 6 & & & & 1 & & 2 & & 7 & 12 \\
\hline $\begin{array}{l}\text { уміння висловлювати власну } \\
\text { думку усно та письмово }\end{array}$ & 4 & 6 & & & & 2 & & 2 & & 4 & 14 \\
\hline критичне та системне мислення & 6 & 7 & & & & 4 & & 2 & & 7 & 11 \\
\hline уміння діяти творчо & 2 & 8 & 1 & & & 0 & & 3 & & 5 & 16 \\
\hline інноваційність & 5 & 6 & & & & 3 & & 2 & & 6 & 13 \\
\hline $\begin{array}{l}\text { уміння логічно обгрунтовувати } \\
\text { позицію }\end{array}$ & 4 & 7 & & & & 2 & & 3 & & 4 & 15 \\
\hline уміння керувати емоціями & 3 & 9 & & & & 1 & & 2 & & 7 & 14 \\
\hline $\begin{array}{l}\text { уміння оцінювати ризики та } \\
\text { приймати рішення }\end{array}$ & 5 & 6 & & & & 3 & & 3 & & 7 & 11 \\
\hline уміння розв'язувати проблеми & 5 & 7 & & & & 2 & & 2 & & 4 & 14 \\
\hline уміння співпрацювати з іншими & 1 & 5 & & & & 0 & & 3 & & 4 & 17 \\
\hline середнє значення & 3,9 & 6,7 & 7 , & 5 , & & 1,8 & & 3 & &, 5 & 13,7 \\
\hline
\end{tabular}


Аналіз отриманих даних (табл. 3) демонструє значний приріст показників високого рівня всіх наскрізних умінь учнів 3-4 класу за результатами формувального етапу дослідження. Найбільш позитивними відбулися зміни у сформованості умінь діяти творчо, розв'язувати проблеми та логічно обгрунтовувати позицію.

Таблиия 3

Узагальнені дані сформованості наскрізних умінь учнів 5-6 класів у порівнянні (на констатувальному та контрольному етапах дослідження)

\begin{tabular}{|c|c|c|c|c|c|c|c|c|}
\hline \multirow[b]{2}{*}{ Наскрізні уміння } & \multicolumn{4}{|c|}{$\begin{array}{c}5 \text { клас (22 особи) } \\
\text { констатувальний етап }\end{array}$} & \multicolumn{4}{|c|}{$\begin{array}{c}6 \text { клас (22 особи) } \\
\text { контрольний етап }\end{array}$} \\
\hline & $\Pi$ & $\mathrm{C}$ & Д & $\mathrm{B}$ & $\Pi$ & $\mathrm{C}$ & Д & $\mathrm{B}$ \\
\hline читання з розумінням & 2 & 4 & 7 & 9 & 0 & 2 & 5 & 15 \\
\hline $\begin{array}{l}\text { уміння висловлювати } \\
\text { власну думку усно та } \\
\text { письмово }\end{array}$ & 4 & 6 & 8 & 4 & 2 & 5 & 6 & 9 \\
\hline $\begin{array}{l}\text { критичне та системне } \\
\text { мислення }\end{array}$ & 4 & 7 & 7 & 4 & 3 & 5 & 5 & 9 \\
\hline уміння діяти творчо & 5 & 8 & 7 & 2 & 2 & 4 & 6 & 10 \\
\hline інноваційність & 6 & 8 & 5 & 3 & 4 & 4 & 6 & 8 \\
\hline $\begin{array}{l}\text { уміння логічно } \\
\text { обгрунтовувати позицію }\end{array}$ & 5 & 12 & 3 & 2 & 2 & 5 & 7 & 8 \\
\hline уміння керувати емоціями & 5 & 8 & 6 & 3 & 4 & 3 & 6 & 9 \\
\hline $\begin{array}{l}\text { уміння оцінювати ризики та } \\
\text { приймати рішення }\end{array}$ & 6 & 8 & 7 & 2 & 2 & 2 & 10 & 8 \\
\hline $\begin{array}{l}\text { уміння розв'язувати } \\
\text { проблеми }\end{array}$ & 8 & 8 & 4 & 2 & 4 & 2 & 5 & 11 \\
\hline $\begin{array}{l}\text { уміння співпрацювати } 3 \\
\text { іншими }\end{array}$ & 5 & 4 & 7 & 6 & 2 & 4 & 5 & 11 \\
\hline середнє значення & 5 & 7,3 & 6,1 & 3,7 & 2,5 & 3,6 & 6,1 & 9,8 \\
\hline
\end{tabular}

Порівняння результатів констатувального і контрольного етапів дослідження сформованості наскрізних умінь учнів 5-6 класу, демонструє хоч i не значний приріст показників високо рівня, проте присутню динаміку в розвитку всіх наскрізних умінь (табл. 3 ).

Значні позитивні зміни в учнів 6 класу відбулися у сформованості умінь розв'язувати проблеми, приймати рішення, обгрунтовувати позицію та діяти творчо. Про підвищення рівнів сформованості наскрізних умінь учнів експериментального класу (5-6) зазначали і вчителі, які мали змогу порівняти успішність цих учнів 3 учнями паралельних класів. Зокрема вчителями відзначено, що учні експериментального класу стали активнішими в обговореннях проблемних питань, висуненні гіпотез, відстоюванні своїх думок та застосовують більше різноманітних інформаційних ресурсів та сервісів для пошуку необхідної інформації. 
Журнал«Герспективитаінновації наукиљ

(Серія «Гедагогіка», Серія«ГЕихологія», Серія«Медицина»

№1(6) 2022

Ми свідомі того, що підвищення рівня сформованості наскрізних умінь в учнів 3-4 та 5-6 класів відбувалося не лише завдяки запропонованих нами вебквестів, а й у результаті їхнього навчання та вікового зростання. Однак висловлені думки вчителів, які мали змогу порівнювати результати навчання та успішності учнів паралельних класів, доводять якісні зміни у сформованості наскрізних умінь учнів експериментальних класів, що у свою чергу, доводить ефективність розробленого нами та реалізованого змістовнотехнологічного забезпечення (рис. 2).

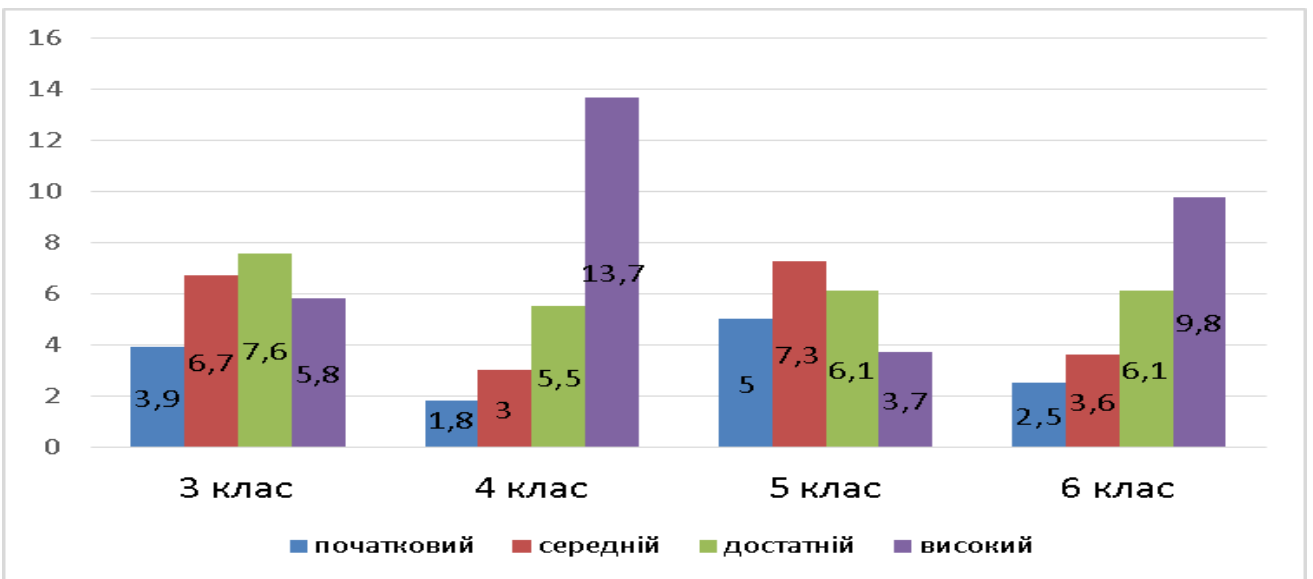

Рис. 2. Порівняння середніх значень рівнів сформованості наскрізних умінь учнів 3-4 і 5-6 класів на констатувальному та контрольному етапах дослідження

Висновки. Перевірка результативності розробленого змістовотехнологічного забезпечення формування наскрізних умінь засобом вебквестів учнів 3-4 та 5-6 класів, яка здійснювалася у відповідності до розробленої методики дослідження, довела його ефективність. Це засвідчує великий потенціал вебквестів у роботі зі здобувачами базової середньої освіти, які навчатимуться за новими стандартами. Детальний аналіз отриманих результатів на контрольному етапі дослідження демонструє вищі результати в учнів початкових класів. Маємо припущення, що це пов'язано 3 систематичною роботою вчителів, які працюють за реформою НУШ. Адже формуванню наскрізних умінь в учнів 5-6 класів, які не навчаються за Концепцією НУШ, вчителі не надають значної уваги і роботу 3 даного напрямку не проводять систематично.

Проведене дослідження не вирішує всіх проблем щодо формування наскрізних умінь в учнів базової середньої освіти. Подальшого вивчення потребують питання оновлення змісту, форм, методів і засобів формування та оцінювання умінь учнів з урахуванням змісту Державного стандарту базової середньої освіти.

\section{Лimepamypa:}

1. Державний стандарт початкової освіти : Постанова КМУ від 21.02.2018 p. № 87. Дата оновлення: 24.07 .2019 p. № 688. URL: https://zakon.rada.gov.ua/laws/show/87-2018$\% \mathrm{D} 0 \% \mathrm{BF} \# \mathrm{n} 12$ (дата звернення 10.11.2021). 
2. Державний стандарт базової середньої освіти : Постанова КМУ від 30.09.2020 p. № 898. URL: https://www.kmu.gov.ua/npas/pro-deyaki-pitannya-derzhavnih-standartiv-povnoyizagalnoyi-serednoyi-osviti-i300920-898 (дата звернення 9.11.2021).

3. Колесникова I. В. Наступність та перспективність навчання інформатики в НУШ. Базова освіта НУШ: процесуальне правонаступництво : зб. матеріалів регіонал. наук.-практ. інтернет-конференції, м. Житомир, 29 берез. 2021 р. Житомир: КЗ «Житомирський ОІППО» ЖОР, 2021. С. 44-47.

4. Результати дослідження наскрізних умінь учнів початкової школи. URL: https://mon.gov.ua/storage/app/media/nova-ukrainska-

shkola/2021/Monitorynh/Rezultaty\%20doslidzhennya\%20naskriznykh\%20umin\%20uchniv\%20po chatkovoyi\%20shkoly_26_02.pdf (дата звернення 29.10.2021).

5. Роміцина Л. В. Ключові компетентності та наскрізні вміння - основа математичної освітньої галузі Державного стандарту базової середньої освіти. Базова освіта НУШ: процесуальне правонаступництво : зб. матеріалів регіонал. наук.-практ. інтернет-конференції, м. Житомир, 29 берез. 2021 р. Житомир: КЗ «Житомирський ОІППО» ЖОР, 2021. С. 64-67.

\section{References:}

1. Derzhavnyi standart pochatkovoi osvity : Postanova KMU vid 21.02.2018 r. № 87. Data onovlennia: 24.07.2019 r. № 688 [State standard of primary education: Resolution of the Cabinet of Ministers of 21.02.2018 № 87. Date of renewal: 24.07.2019 № 688.]. (n.d.). zakon.rada.gov.ua. Retrieved from https://zakon.rada.gov.ua/laws/show/87-2018-\%D0\%BF\#n12 [in Ukrainian].

2. Derzhavnyi standart bazovoi serednoi osvity : Postanova KMU vid 30.09.2020 r. № 898. [State standard of basic secondary education: Resolution of the Cabinet of Ministers of 30.09.2020 № 898]. (n.d.). kmu.gov.ua. Retrieved from https://www.kmu.gov.ua/npas/pro-deyaki-pitannyaderzhavnih-standartiv-povnoyi-zagalnoyi-serednoyi-osviti-i300920-898 [in Ukrainian].

3. Kolesnykova I. V. (2021). Nastupnist ta perspektyvnist navchannia informatyky v NUSh. [Continuity and prospects of teaching computer science at NUS]. Materialy rehionalnoi naukovopraktychnoi internet-konferentsii «Bazova osvita NUSh: protsesualne pravonastupnytstvo» Proceedings of the regional scientific-practical Internet conference «Basic education of NUS: procedural succession». (pp. 44-47). Zhytomyr: KZ «Zhytomyrskyi OIPPO» [in Ukrainian].

4. Rezultaty doslidzhennia naskriznykh umin uchniv pochatkovoi shkoly [The results of the study of cross-cutting skills of primary school students]. (n.d.). mon.gov.ua. Retrieved from https://mon.gov.ua/storage/app/media/nova-ukrainska-

shkola/2021/Monitorynh/Rezultaty\%20doslidzhennya\%20naskriznykh\%20umin\%20uchniv\%20po chatkovoyi\%20shkoly_26_02.pdf [in Ukrainian].

5. Romitsyna L. V. (2021). Kliuchovi kompetentnosti ta naskrizni vminnia - osnova matematychnoi osvitnoi haluzi Derzhavnoho standartu bazovoi serednoi osvity [Key competencies and cross-cutting skills are the basis of the mathematical education field of the State Standard of Basic Secondary Education]. Materialy rehionalnoi naukovo-praktychnoi internet-konferentsii «Bazova osvita NUSh: protsesualne pravonastupnytstvo» - Proceedings of the regional scientificpractical Internet conference «Basic education of NUS: procedural succession». (pp. 64-67). Zhytomyr: KZ «Zhytomyrskyi OIPPO» [in Ukrainian]. 